\title{
Effects of the Same-Gender vs. Cross-Gender Mentoring on a Protégé Outcome in Academia: An Exploratory Study
}

\author{
Metka Kogovšek $^{1} \quad$ Irena Ograjenšek ${ }^{2}$
}

\begin{abstract}
Mentoring seems to be an important way to start and advance individual researcher's career in science. Therefore, it is essential to examine the factors related to successful mentoring in order to find ways of efficiently supporting young academics on their career development path. Building on the similarity-attraction and social identity theories, our research indicates that gender similarity in academic mentoring might be related to the protégés' postdoctoral publication scores that lead to career advancement. The scores in a typical five-year publication cycle are higher for the protégés situated within same-gender mentoring dyads. Furthermore, the mentors' research performance importantly adds to the protégés' postdoctoral research performance.
\end{abstract}

\section{Introduction}

The concept of mentoring is defined as a process in which an advanced person serves as a role model while teaching and coaching a less skilled, less experienced individual with the aim of aiding the person in his/her career development (Sorcinelli and Yun, 2007). Therefore, the process of mentoring has always been highly valued.

The term mentor originates from the Greek mythology where Mentor, a personification of the goddess Athena, was a counselor to Telemachus. She educated and protected Telemachus during his maturation process and supported him in his endeavors to become a king (Russell and Adams, 1997). In Renaissance, mentoring was a widely accepted method for educating young individuals (Çetin, Kizil and Zengin, 2013). Nowadays, it is acknowledged as the process of preparing a person to become a full member of the certain profession (Johnson, 2002).

Due to its importance, the literature on mentoring has been growing exponentially (Colley, 2001), with the focus mostly on positive mentoring results. These include smoother career advancement that is mostly reflected in higher salary, higher level of job satisfaction, motivation and organizational commitment (Ensher, Grant-Vallone and Marelich, 2002; Dickson et al., 2014; Ghosh, 2014; Scandura and Williams, 2001); career satisfaction, retention, lower turnover (Raabe and Beehr, 2003); reduced level of stress (Gardiner

\footnotetext{
${ }^{1}$ Faculty of Economics, University of Ljubljana, Ljubljana, Slovenia; metka.kogovsek@ guest.arnes.si

${ }^{2}$ Faculty of Economics, University of Ljubljana, Ljubljana, Slovenia; irena.ograjensek@ef.uni-lj.si
} 
et al., 2007); and in greater work efficiency (Dickson et al. 2014). Mentoring seems to fulfill career aspirations (Kurtz-Costes, Helmke and Ülkü-Steiner, 2006) and supports professional as well as personal growth (Ponce, Williams and Allen, 2005; Scandura and Williams, 2001). Ghosh (2014) adds that a protégé might, due to being under mentor's supervision, more probably survive within the extremely dynamic work environment.

Mentoring is especially important in the academia. Kurtz-Costes, Helmke and ÜlküSteiner (2006), implementing a qualitative study, report that all the academics agree about the importance of mentoring. In academia, mentoring is crucial in the early career stages, starting with the doctoral studies and continuing at least to the stage when an individual becomes a full member of the academic community (Searby and Tripses, 2006).

The matching process is important when assigning a mentor to a protégé while the mentor needs to be open for gender issues (Füger and Höppel, 2011). Regular mentoring and supervisors' support is one of the most important factors of doctoral students' success (Kogovšek, Hlebec and Ferligoj, 2011). Hlebec, Kogovšek and Ferligoj (2011) conclude that mentors' support and support within the academic networks are even more important than doctoral student motivation although the latter is a rather important predictor in every respect. The researchers (Coromina, Coenders, Ferligoj and Guia, 2011; Ziherl, Iglič and Ferligoj, 2006) go deeper into analyzing the mentor-protégé dyads in relation with wider research collaboration that might result in either weak social capital, strong social capital of a bonding kind, or a strong social capital of bridging type dyads.

Despite these very relevant studies, there is a lack of research evidence on the correlations between gender mentoring structure and the mentoring outcomes (Allen, Eby and Lentz, 2006; Muschallik and Pull, 2016; O'Brien et al., 2010). Although several studies in the past have focused on the mentor-protégé dynamics, the research demonstrating the correlation between the gender mentoring composition and protégé's research productivity is limited (de Janasz and Sullivan, 2004). Specifically, Lankau, Riordan and Thomas (2005) hypothesize that the interpersonal comfort (the same-gender mentoring relationship deemed to bring about a higher interpersonal comfort) in the academic mentoring process might be related to research productivity of a protégé. Therefore, O'Brien et al. (2010) call for in-depth research on gender composition of the mentoring dyads.

Consequently, the purpose of our empirical study is to address this gap in the literature. We aim to explore the existence of differences in research productivity of the protégés situated within the same versus the cross-gender mentoring dyads during their doctoral studies, with the focus on the formal mentoring programs within the traditional mentorprotégé relationships. It is rather significant to identify, whether gender composition of a mentoring dyad might influence the academic results a protégé finally achieves.

The paper is divided into five sections. After the introduction, the second section reviews the literature on mentoring with the additional focus on the mentors' research productivity that might be significantly impacting the postdoctoral research productivity of the protégés. The third section is dedicated to the description of our research framework. Our empirical results are presented in the fourth section. The final section contains discussion and recommendations for future research. 


\section{Theoretical Background}

\subsection{The Concept of Mentoring}

Mentoring might be established within the traditional senior/junior mentoring dyad, or in the framework of alternative mentoring models such as peer mentoring, team mentoring, or e-mentoring (Sorcinelli and Yun, 2007). Our study focuses on traditional relationship between a mentor and a protégé that develops within a classic hierarchical setting where a protégé needs to follow the directions of her/his mentor (Alvarez and Lazzari, 2016; Savage, Karp and Logue, 2004) and thus receives the required knowledge, advice and support in order to thrive in academia (Kochan and Trimble, 2000).

The mentoring process encompasses several domains of individual interactions including the developmental, psychological, and the role modeling with the aim of supporting a protégé (Ghosh, 2014). Thus, mentors in academia perform a triple function. The psychological one is demonstrated by being empathetic when a protégés faces problems and advising a protégé on balancing work and family obligations; in short by guiding, counseling, motivating, and advising a protégé in different spheres of his/her working life. The instrumental one is key for development of a protégé's teaching and research skills as well as for strengthening his/her self-image and self-efficacy. Finally, the networking function (in form of sponsoring, adding to protégé's visibility, introducing a protégé to the important individuals within own academic networks) lays the groundwork for a protégé's successful career advancement (Ghosh, 2014; Ortiz-Walters and Gilson, 2005). Not to be neglected (although probably already embedded in the networking function) is the important political aspect of mentoring, which entails engagement of mentor's resources and power (Kirchmeyer, 2005).

Townsend (2002) believes the best mentors to be those who are approachable, supportive, and those who invest a lot of time and energy in the mentoring process. Additionally, different authors claim that mentors as role models (Barlow, 2005; Ghosh, 2014; Lankau, Riordan and Thomas, 2005) serve as a living example of the values and ethical professional practices.

\subsection{Measurement of Mentoring Benefits}

The benefits of mentoring are not easy to measure quantitatively (Merriam, Thomas and Zeph, 1987). The mentoring outcomes are mostly measured by promotion rates (Koberg et al., 1994). Meta-analysis suggests that all the mentoring functions have a rather high predicting power of mentoring outcomes regarding employee development (Dickson et al., 2014). Specifically, the longitudinal studies offer insights about benefits of academic mentorship being not only the enhancement of self-efficacy of a protégé but also his/her research performance (Paglis, Green and Bauer, 2006). Assessing performance in academia means identifying publication productivity, which in fact impacts career advancement of the academics across academic disciplines (Kirchmeyer, 2005; Lopez et al., 2014; Paik et al., 2014). Academic mentoring might be correlated to protégés' career success not only at the early stage of the career but also later on (Sorcinelli and Yun, 2007; Van Eck Peluchette and Jeanquart, 2000).

During the past few decades, much attention has been devoted to examining research 
productivity (Abramo, Cicero and D'Angelo, 2015; Blackburn, Behymer and Hall, 1978; Bordons et al., 2003; Eloy et al., 2013; Kirchmeyer, 2005; Paglis, Green and Bauer, 2006) wherein scientific publications are the main research output. Assessments of research performance use publication-based and bibliometric indicators (Bordons et al., 2003). Many researchers apply the quantitative approach to measuring research productivity by analyzing the number of publications. However, studies focusing on the raw output measures (such as the number of published articles) have been criticized for neglecting the nature of the work and communication between the researchers (Hunter and Leahey 2010) because they would not provide a correct depiction of research productivity in the terms of quality. Yet the number of citations is a quantitative expression of the acceptance and visibility of academic research. It therefore reflects the quality of a research publication (Gu et al., 2011). Eloy et al. (2013) use another objective measure of research contribution, namely h-index, which quantifies the number and significance of papers published by an author.

\subsection{Gender Similarity of Academic Mentoring and Protégés' Future Research Outcome}

Due to the complex nature of mentoring relationships, Dickson et al. (2014) identify several factors that impact them, namely personal (protégé's level of proactive personality dimension, protégé's learning orientation, level of mentor's transformational leadership); relational (trust, perceived similarity); and organizational (organizational support).

Our study focuses on the relational aspects of mentoring. Here, mentoring models are founded in a collectivistic philosophy wherein career (instrumental, goal-oriented function) and psychological (nurturance function) support is offered to a less knowledgeable person, resources are shared, and frequent feedback delivered (Ponce, Williams and Allen, 2005). The complexity of mentoring can be analyzed through the lens of the relational theory wherein the interpersonal relationships need to be authentic to achieve mutuality (Alvarez and Lazzari, 2016) and where the individuals exhibit the sense of caring for another since the theory is built upon the primary need for emotional connection. The mutuality goes even beyond the traditional hierarchical structure of mentoring process and opens a space for critical deliberation and independent learning (Beyene et al., 2002).

Although some (Meerabeau, 2005) claim that females are usually dedicated to mentoring more profoundly than males, others (Nolan, 1992) ascertain that the elements of high-quality mentoring are not attributed to a specific gender of the mentor. However, a [gender] mismatch of a mentorship dyad due to its complexity and dynamic nature (Barker, 2006) might cause relational problems and result in lower mentoring outcomes (Bell and Treleaven, 2011; Eby and McManus, 2004).

Successful mentoring requires an establishment of a genuine relationship wherein mentor assists a protégé in her/his endeavors for success (Scandura and Williams, 2001; Straus, Chatur and Taylor, 2009; Villarroya et al., 2008). Within the framework of the similarity-attraction theory, Menges (2016) ascertains that personal relations which occur within a mentoring relationship impact the delivered results wherein the gender-similarity of mentoring might bring higher psychological as well as career support to a protégé (Ensher, Grant-Vallone and Marelich, 2002). The similarity-attraction paradigm assumes that when a mentor and a protégé are similar, they are more likely attracted to each other there- 
fore the mentoring relationship is more fruitful (Villarroya et al., 2008) because a mentor is highly motivated to support a protégé. The mentor-protégé relationship fructifies in a higher-quality mentoring support due to a stronger common bond as the consequence of their mutual identification (Scandura and Williams, 2001). There is a correlation between the intensity of the relationship between two individuals and perceived benefits that result in individuals presuming that there will be more to gain when one invests more in a certain relationship (Straus, Chatur and Taylor, 2009).

Although Lankau, Riordan and Thomas (2005) correlate gender-similarity with higher psychological support as well as role-modelling, and consider that the cross-gender mentoring relationship might result in different issues that impede the level of career and psychological support to a protégé, they further argue that it is not the same-gender dyads per se that elicit greater mentoring effectiveness but rather the interpersonal (dis)comfort. According to the assumptions of the social identity theory, the same-gender mentoring relationship leads to a higher interpersonal comfort, which might further result in a higher protégé academic performance compared to the cross-gender mentoring dyad (Ragins, 1997). Furthermore, Allen, Day and Lentz (2005) add that gender similarity does not bring about only higher interpersonal comfort, but also higher relationship quality which results in stronger support offered to the protégé. Although similarity of the mentoring relationship's gender composition seems to be deemed significant, some researchers (Ugrin, Odom and Pearson, 2008) claim that greater scientific results might emerge within the cross-gender dyads.

Our research aims to compare the success of the same versus cross-gender dyads within the formal mentoring programs, taking into account the objective mentoring outcomes of the protégés, namely their postdoctoral publication and citation scores. Thus, from the performance perspective, we assume that strong mentoring support, due to strong interpersonal relationship, would lead to higher protégé research performance. Additionally, interpersonal comfort and stronger emotional relationship, due to emotional closeness, would result in the higher quality of mentoring. Therefore, gender-similar mentoring dyads would result in higher postdoctoral research productivity of the protégés. This is in line with Weinberg and Lankau's (2011) claim that formal mentoring relationship deepens over a longer period, therefore the negative effects of cross-gender relationships might disappear rather slowly. Our first hypothesis is therefore as follows:

H1: The protégés, situated within the same-gender mentoring dyads during their doctoral studies, attain significantly better postdoctoral research productivity scores compared to those situated within the cross-gender mentoring dyads.

\subsection{Mentors' Research Productivity Scores and the Protégés' Career Development}

Due to the importance of the mentoring relationship during the dissertation preparation process, our empirical study further aims to identify the predicting value of mentor's qualifications (regarding his/her research productivity at the time a protégé finishes his/her doctoral studies) on a protégé's postdoctoral research productivity. Namely, many researchers (Capó et al., 2007; Gu et al., 2011; Matelič, Mali and Ferligoj, 2007; Smith et 
al., 2008; Williamson and Cable, 2003) also ascertain that protégés' research productivity strongly correlates with mentors' research productivity scores.

Within a complex academic environment, the mentors offer the protégés moral support as well as support regarding building scholarly values, publishing scientific articles and preparing research grant applications and thus impact the protégés' post-appointment research productivity (Williamson and Cable, 2003). Therefore, our second hypothesis is as follows:

H2: The mentors' research productivity scores in a year of a protégé's graduation from the doctoral studies program correlate significantly with the protégés' postdoctoral research productivity.

\section{Research Design}

The data for our empirical research were obtained from the SICRIS database of the Slovenian Research Agency (ARRS). The database combines data from the Web of Science and Scopus for evaluation of citing score, h-index, and similar indices. It serves as a common database on the research performance of all registered researchers in Slovenia, also providing the data on their past and current employment.

In our research project, we focused our attention on a single faculty within the University of Ljubljana (Faculty of Economics, with academics from the fields of economics and business). Data on the individuals employed by this faculty were collected from its website (www.ef .uni-lj.si). For evaluation of research productivity, two different parameters were used, namely publishing and citing score, respectively. The study is thus based on the quantitative research design using objective measures. The data on research performance were collected for the second, and, wherever available, also for the fifth, the eighth and the tenth year after each individual completed his/her doctoral studies. Information on each candidate's dissertation mentor was obtained from the COBISS database. All our data were retrieved in the period from May 3rd to May 15th, 2016.

Coupling the data from different sources (the SICRIS database, the COBISS database, and the faculty's website) resulted in a dataset of all full-time employed academics (with the exception of the sports and language teachers) who obtained their doctoral degree in the period 1995 to 2013. This resulted in the database of 76 (39 female and 37 male) academics. The year 1995 was chosen because it is a milestone when the career development requirements at the University of Ljubljana changed significantly. In our view, it only makes sense to compare the academic publishing indices for those academics who have faced similar career development conditions. The academics, employed by the Faculty of Economics who won their doctoral degrees in 2013 or later, are not included because the mentoring benefits might not be detected for several years to come (the time-lag effect).

The mentoring dyads in our sample are grouped according to the categorization scheme introduced by Ragins (1997) who utilizes diversified mentoring relationships in explaining the corresponding mentoring outcomes.

For the purpose of our study, both the same and cross-gender dyads were examined. Table 1 shows the frequencies and structure of examined dyads. We focused on the formal type of mentoring relationships targeting one-to-one mentoring model and assessing 
Table 1: Overview of dyads in the sample

\begin{tabular}{lrr}
\hline Type of dyad & Frequency & Percent \\
\hline Initial four gender mentoring dyads & & \\
\hline Female mentor-female protégé mentoring dyads & 13 & 17.60 \\
Male mentor-male protégé mentoring dyads & 27 & 36.50 \\
Female mentor-male protégé mentoring dyads & 9 & 12.20 \\
Male mentor-female protégé mentoring dyads & 25 & 33.80 \\
Total & 74 & 100.00 \\
\hline Same versus cross-gender mentoring dyads & & \\
\hline Same gender mentoring dyads & 40 & 54.10 \\
Cross-gender mentoring dyads & 34 & 45.90 \\
Total & 74 & 100.00 \\
\hline
\end{tabular}

protégés' research performance as the significant indicator of the mentoring output. Both types of the same-gender and cross-gender dyads are pooled in order to balance out our sample.

Table 2 contains descriptive statistics of all the predictors, namely the protégés' indicators A1, A2 and A for two, five, eight and ten years after $\mathrm{PhD}$ graduation together with the mentors' $\mathrm{A} 1$ and $\mathrm{A} 2$ indicators.

\section{Empirical Results}

Many researchers report on lower research productivity of female academics, especially at the beginning of their academic careers (Eloy et al., 2013; Kaufman and Chevan, 2011). To examine the specifics of our sample, we thus firstly checked for gender differences in the research productivity of academics employed by the Faculty of Economics, conducting the independent-sample $t$-tests.

The independent-sample $t$-test is conducted to gain the data on the differences in the research productivity as a variable related to an academic mentoring outcome that might be correlated with the gender structure of the mentoring dyad. We hypothesized that gender similarity of a mentoring dyad might provide for the higher quality relationship between a mentor and a protégé, which results in better mentoring outcomes regarding postdoctoral research productivity scores of the protégés.

As presented in Table 3, the independent sample $t$-test shows statistically significant higher research productivity mean scores for the group of male academics compared to the group of female academics only for citation and total scores in the second and fifth year after graduation from the doctoral study program.

The research productivity differences of the academics situated within the analyzed gender mentorship dyads are presented in Table 4.

There are 40 same-gender and 34 cross-gender mentoring dyads included in analysing the differences in the protégés' research indicators two years after graduation from the doctoral program between protégés situated in same-gender mentoring dyads versus proté- 
Table 2: Descriptive statistics of the predictors

\begin{tabular}{lrrrrc}
\hline Variable (Indicator) & $\mathrm{N}$ & Min & Max & $\mathrm{M}$ & $\mathrm{SD}$ \\
\hline Two years after obtaining & a PhD & degree \\
\hline Publications (A1) & 74 & 0.00 & 3.60 & 0.644 & 0.613 \\
Citations (A2) & 74 & 0.00 & 6.32 & 0.599 & 0.987 \\
Total score (A) & 74 & 0.00 & 1.24 & 1.243 & 1.442 \\
\hline Five years after obtaining a PhD degree \\
\hline Publications (A1) & 58 & 0.10 & 5.60 & 1.376 & 0.996 \\
Citations (A2) & 58 & 0.00 & 10.00 & 1.318 & 2.241 \\
Total score (A) & 58 & 0.13 & 15.64 & 2.694 & 3.045 \\
\hline Eight years after obtaining a PhD degree & & \\
\hline Publications (A1) & 42 & 0.31 & 5.31 & 2.151 & 1.260 \\
Citations (A2) & 42 & 0.00 & 10.00 & 2.043 & 2.586 \\
Total score (A) & 42 & 0.30 & 14.90 & 4.193 & 3.549 \\
\hline Ten years after obtaining a PhD & degree \\
\hline Publications (A1) & 25 & 1.16 & 4.84 & 2.728 & 1.090 \\
Citations (A2) & 25 & 0.00 & 10.00 & 2.651 & 2.413 \\
Total score (A) & 25 & 1.30 & 13.90 & 5.379 & 3.129 \\
\hline Mentors' indicators in a year of a protégé's gradua- \\
tion from the doctoral study program \\
\hline Publications (A1) & 74 & 0.00 & 1.00 & 0.250 & 0.254 \\
Citations (A2) & 74 & 0.00 & 10.00 & 2.340 & 3.237 \\
Total (A) & 74 & 0.00 & 10.83 & 2.590 & 3.343 \\
\hline
\end{tabular}

gés situated in cross-gender mentoring dyads. Research productivity scores are not normally distributed, as assessed by Shapiro-Wilk's test $(p>.05)$, and there is homogeneity of variances, as assessed by Levene's test for equality of variances $(p>.05)$ except for the indicator A2 $(p=.029)$. The results show no statistically significant differences between the same- and cross-gender mentoring dyads.

Five years after graduation from the doctoral program, there are 32 same-gender and 26 cross-gender mentoring dyads included in analysing the differences in the protégés' research indicators. Again, research productivity scores are not normally distributed as assessed by Shapiro-Wilk's test $(p>.05)$, except for the same-gender mentoring dyad indicator A1, and the homogeneity of variances, as assessed by Levene's test for equality of variances is violated $(p<.05)$. However, the results do show higher research productivity scores for the group of academics that are situated in the same-gender mentoring dyads compared to the group of academics situated within the cross-gender mentoring dyads.

Eight years after graduation from the doctoral program, there are 22 same-gender and 21 cross-gender mentoring dyads included in analysing the differences in the protégés' research indicators. Research productivity scores are not normally distributed, as assessed 
Table 3: Research productivity gender differences

\begin{tabular}{lcccccc}
\hline & \multicolumn{2}{c}{ Females } & & \multicolumn{2}{c}{ Males } & Diff \\
\cline { 2 - 3 } \cline { 7 - 7 } Variable (Indicator) & $\mathrm{M}$ & $\mathrm{SD}$ & $\mathrm{M}$ & $\mathrm{SD}$ & $t$ \\
\hline Research indicators & two years & after & obtaining & a & PhD & degree \\
\hline Publications (A1) & 0.514 & 0.403 & 0.774 & 0.746 & 1.873 \\
Citations (A2) & 0.312 & 0.450 & 0.890 & 1.264 & $2.626^{*}$ \\
Total score (A) & 0.827 & 0.671 & 1.664 & 1.840 & $2.609^{*}$ \\
\hline Research indicators & five years & after & obtaining & a & PhD & degree \\
\hline Publications (A1) & 1.193 & 0.773 & 1.606 & 1.174 & 1.638 \\
Citations (A2) & 0.726 & 0.904 & 2.088 & 3.047 & $2.206^{*}$ \\
Total score (A) & 1.919 & 1.572 & 3.693 & 4.003 & $2.138^{*}$ \\
\hline Research indicators & eight years & after & obtaining & a PhD & degree \\
\hline Publications (A1) & 1.953 & 1.158 & 2.426 & 1.324 & 1.267 \\
Citations (A2) & 1.568 & 2.134 & 2.746 & 2.947 & 1.557 \\
Total score (A) & 3.521 & 3.074 & 5.172 & 3.865 & 1.592 \\
\hline Research indicators & ten years & after & obtaining & a PhD & degree \\
\hline Publications (A1) & 2.478 & 1.112 & 3.184 & 0.894 & 1.690 \\
Citations (A2) & 2.790 & 2.697 & 2.665 & 1.998 & -0.126 \\
Total score (A) & 5.268 & 3.494 & 5.849 & 2.633 & 0.450 \\
\hline
\end{tabular}

by Shapiro-Wilk's test $(p>.05)$, except for the cross-gender mentoring dyad indicator A1 and A. There is homogeneity of variances, as assessed by Levene's test for equality of variances $(p>.05)$ for the indicator A1 but not for the indicators A2 and A $(p<.05)$. The results show no statistically significant differences in the eighth year after graduation from the doctoral program between the same- and cross-gender mentoring dyads.

Finally, there are 12 same-gender and 13 cross-gender mentoring dyads included in analysing the differences in the protégés' research indicators ten years after graduation from the doctoral program. All research productivity scores, with the exception of the A2 indicator, are normally distributed, as assessed by Shapiro-Wilk's test $(p>.05)$. There is homogeneity of variances, as assessed by Levene's test for equality of variances $(p>.05)$, for all the indicators. The results show no statistically significant differences in the tenth year after graduation from the doctoral program between the same- and crossgender mentoring dyads.

All in all, the analysis shows that the performance differences in research productivity scores (indicators A1, A2, and A) between the academics situated within the same-gender compared to those situated within the cross-gender mentoring dyads are statistically significant in the fifth year after graduation from the doctoral study program. In our opinion, this reflects the average period in which the dissemination process of the work carried out in the framework of the doctoral dissertation comes to fruition. Later on, the protégé enters a new research and publication cycle, which might be completely independent of 
Table 4: Differences in research productivity of the same- vs. cross-gender mentoring dyads

\begin{tabular}{|c|c|c|c|c|c|}
\hline \multirow[b]{2}{*}{ Variable (Indicator) } & \multicolumn{2}{|c|}{ Cross-gender dyad } & \multicolumn{2}{|c|}{ Same-gender dyad } & \multirow{2}{*}{$\begin{array}{c}\text { Diff } \\
t\end{array}$} \\
\hline & M & SD & M & SD & \\
\hline \multicolumn{6}{|c|}{ Research indicators two years after obtaining a PhD degree } \\
\hline Publications (A1) & 0.561 & 0.476 & 0.709 & 0.696 & -1.064 \\
\hline Citations (A2) & 0.418 & 0.582 & 0.743 & 1.205 & -1.533 \\
\hline Total (A) & 0.979 & 0.860 & 1.452 & 1.753 & -1.455 \\
\hline \multicolumn{6}{|c|}{ Research indicators five years after obtaining a PhD degree } \\
\hline Publications (A1) & 1.095 & 0.617 & 1.599 & 1.159 & $-2.152 *$ \\
\hline Citations (A2) & 0.740 & 0.879 & 1.787 & 2.795 & $-2.032 *$ \\
\hline Total (A) & 1.835 & 1.263 & 3.386 & 3.755 & $-2.224 *$ \\
\hline \multicolumn{6}{|c|}{ Research indicators eight years after obtaining a PhD degree } \\
\hline Publications (A1) & 2.022 & 1.086 & 2.258 & 1.376 & -0.637 \\
\hline Citations (A2) & 1.450 & 1.432 & 2.603 & 3.184 & -1.577 \\
\hline Total (A) & 3.472 & 2.261 & 4.860 & 4.265 & -1.373 \\
\hline \multicolumn{6}{|c|}{ Research indicators ten years after obtaining a PhD degree } \\
\hline Publications (A1) & 2.466 & 1.085 & 3.080 & 1.003 & -1.487 \\
\hline Citations (A2) & 3.333 & 2.834 & 2.052 & 1.655 & 1.375 \\
\hline Total (A) & 5.799 & 3.696 & 5.132 & 2.472 & 0.531 \\
\hline
\end{tabular}

the mentor. Consequently, our first hypothesis is confirmed.

At the second stage of the analysis we aim to identify the significance of the mentors' research productivity at the time of a protégé's graduation from the doctoral study program for the postdoctoral research productivity of the protégés.

For the purpose of regression analysis, the sample of academics included is slightly reduced, since there are no data available in the SICRIS database on the research productivity scores for two of the mentors. The results of the inter-correlations between variables are presented in Table 5 for 58 academics (that completed their doctoral studies in the period from 1995 to 2010) and their respective mentors' research productivity at the time of the protégés' graduation from the doctoral study program. Regarding gender composition of the mentoring dyads, a dummy variable is introduced to indicate the extent to which gender similarity of academic mentoring correlates to mentoring outcomes.

As evident from Table 5, a protégé's publication score for the fifth year after graduation from the doctoral study program is positively related to a mentor's citation score in the year of a protégé's graduation, and also significantly correlated to gender similarity of academic mentoring. However, the examined correlations between exploratory variables, used further in the regression analysis, are not a cause of concern since the metric instrument does not show significant correlations between the exploratory variables that could elicit the problem of multicollinearity.

The multiple linear regression results are presented in Table 6. Regression diagnostics 
Table 5: Correlation coefficients for the fifth year after graduation from the doctoral study program

\begin{tabular}{lccccc}
\hline Category & Protégé A1 & Protégé A2 & Mentor A1 & Mentor A2 & Similarity \\
\hline Protégé A1 & 1.000 & & & & \\
Protégé A2 & $0.729^{* *}$ & 1.000 & & & \\
Mentor A1 & 0.157 & 0.190 & 1.000 & & \\
Mentor A2 & $0.283^{*}$ & $0.403^{* *}$ & 0.257 & 1.000 & \\
Similarity & $0.270^{*}$ & 0.240 & -0.790 & 0.050 & 1.000 \\
\hline
\end{tabular}

Note: A1 - protégé's publication score in a fifth year after obtaining a doctoral degree; A2 protégé's citation score in a fifth year after obtaining a doctoral degree; Mentor A1 - mentor's publication score in a year when a protégé obtained his/her doctoral degree; Mentor A2 - mentor's citation score in a year when a protégé obtained his/her doctoral degree; Similarity - gender similarity of academic mentoring relationship with 1 for the same-gender mentoring dyads and 0 for the cross-gender mentoring dyads; ${ }^{*} p<.05 ;{ }^{* *} p<.01$.

Table 6: Regression results for the fifth year after graduation from the doctoral study program

\begin{tabular}{lccccrrr}
\hline & \multicolumn{3}{c}{ Protégé A1 } & & \multicolumn{3}{c}{ Protégé A2 } \\
\cline { 2 - 4 } \cline { 6 - 8 } Category & $\beta$ & $t$ & $p$ & & $t$ & $p$ \\
\hline Constant & 0.821 & 3.666 & 0.001 & -0.025 & -0.051 & 0.959 \\
Mentor A1 & 0.117 & 0.900 & 0.372 & & 0.116 & 0.929 & 0.357 \\
Mentor A2 & 0.239 & 1.848 & 0.070 & & 0.362 & 2.907 & 0.005 \\
Similarity & 0.268 & 2.130 & 0.038 & & 0.231 & 1.914 & 0.061 \\
\hline$R^{2}$ & 0.158 & & & 0.223 & & \\
$R_{a d j}^{2}$ & 0.112 & & & 0.180 & & \\
$F$ & $3.386^{*}$ & & & $5.171^{* *}$ \\
\hline
\end{tabular}

Note: A1 - protégé's publication score in a fifth year after obtaining a doctoral degree; A2 - protégé's citation score in a fifth year after obtaining a doctoral degree; Mentor A1 - mentor's publication score in a year when a protégé obtained his/her doctoral degree; Mentor A2 - mentor's citation score in a year when a protégé obtained his/her doctoral degree; Similarity - gender similarity of academic mentoring relationship with 1 for the same-gender mentoring dyads and 0 for the cross-gender mentoring dyads; ${ }^{* *} p<.01 ;{ }^{*} p<.05$

are satisfactory. There is also no collinearity problem in the dataset since the tolerance is $>.1$ for both models.

When examining a protégé's publication score in the fifth year after obtaining a doctoral degree, the multiple linear regression analysis yields a statistically significant model, with $R 2=.158$. The mentor's publication and citation scores in a year when a protégé won his/her doctoral degree do not predict a protégé's publication score in the fifth year after graduation. However, the gender similarity of academic mentoring $(\beta=.268, p<.05)$ does significantly predict protégé's publication score in the fifth year after graduation $(F=3.368, p<.05)$ which again confirms our first hypothesis.

Finally, when examining a protégé's citation score for the fifth year after graduation, the regression delivers a statistically significant model, with $R^{2}=.223$ where mentor's 
publication score in a year when a protégé won his/her doctoral degree and gender similarity of academic mentoring do not predict protégé's publication score in the fifth year after graduation. Only the mentor's citation score in a year when a protégé won his/her doctoral degree $(\beta=.362, p<.01)$ statistically significantly predicts protégé's citation score in the fifth year after graduation. Given the common joint publication efforts of a mentoring dyad in a typical 5-year publication cycle, this seems reasonable and thus partly confirms our second hypothesis.

\section{Discussion and Conclusions}

The goal of mentoring in academia is to enable a protégé to become an independent researcher. A mentor acknowledges protégé's strengths at the starting point of his/her developmental pathway while allowing him/her to make mistakes through which one can mature intellectually and gain self-confidence (Gardiner et al., 2007). Therefore, it is essential to understand the factors, related to successful mentoring, to find ways of establishing the measures that might support the academics' career paths.

Most studies on mentoring to date focused on determining significant individual and contextual predictors of successful mentoring. Relation between the gender composition of a mentoring dyad and protégé's research productivity has been identified as potentially of great significance by de Janasz and Sullivan (2004) but not empirically validated.

Our exploratory study contributes to the existing literature by offering empirical evidence to support the claim about significance of the mentoring dyad's gender composition. Drawing from the similarity-attraction theory (which assumes that same-gender dyads bring about greater interpersonal comfort, which facilitates mentoring effectiveness since a protégé can more easily approach his/her mentor) and the social identity theory (which assumes that same-gender mentoring dyad brings about the common identities and experiences that facilitate mentoring effectiveness), adequate pairing of mentors and protégés seems to be significant predictor of a protégé's career success. From the very beginning of the mentoring relationship, gender similarity might entail stronger socio-emotional bonds and stronger support that consequently results in higher research performance.

In our research, we assumed that gender similarity of a mentorship dyad might be significantly correlated to the protégés' postdoctoral research productivity that further leads to academic career advancement. Additionally, we also assumed that the mentors' research productivity positively influences the protégés' postdoctoral research productivity. Our empirical results support both assumptions and offer important insights for practitioners who are striving to build successful mentoring programs in academia. While our findings are relevant for both genders, the efficient gender matching of the mentor-protégé dyads might be deemed indispensable for supporting female academics' career advancement paths within academic environment that is still mostly patriarchal (Nöbauer and Genetti, 2008) and might significantly contribute to increased female participation rates in science.

However, our study also has some limitations that need to be considered. First and foremost, our sample only includes academics from the fields of economics and business, from a school whose globally recognized trademark is gender equality. Consequently, our conclusions might not be generalizable to other academic fields, especially natural 
sciences which are believed to be the domain of men (Arsenjuk and Vidmar, 2015). The gender discrimination in natural sciences is much stronger due to relatively low female representation (Settles et al., 2006). Therefore, different patterns of relationship between a mentor and a protégé might be specific for STEM (science, technology, engineering, and mathematics) disciplines.

The second limitation of our study pertains to the number of variables included in the analysis. Due to its specific focus, our analysis only accounts for the significance of mentors' research productivity and the gender similarity of mentoring relationship although there are other important factors that might contribute to protégés' postdoctoral research productivity, such as availability of funding, inclusion in a research team, and similar.

The third limitation is related to the violated assumption of research productivity score being normality distributed which is especially severe in the second year after doctoral students' graduation. However, the issue is deemed less problematic from the viewpoint of a typical five-year post-doctorate dissemination cycle.

The fourth limitation pertains to other issues that might influence the academic output. Morley (2016) claims that the academic environment features strong neoliberal principles that strengthen competitiveness. Therefore, it is questionable how much knowledge is actually redistributed through academic mentoring (the phenomenon of knowledge hiding).

In the future, it would make sense to replicate this study within other academic fields, thus adding to generalizability of our results. Furthermore, it might be wise to consider a longitudinal research framework, wherein the wider set of factors impacting postdoctoral research productivity could be examined: individual (personal characteristics, motivation, self-efficacy, proactivity, protégés' academic origin, academic qualifications, and so on) as well as contextual (institution's public reputation, departmental scholarly output, intensity of collaboration within formal and informal academic networks, and so on).

Finally, the specifics of the research field, due to several issues the academics face in times when neoliberal principles prevail in the higher education environment (such as intense global and national competition, work overload, massive administration demands, and similar), in our opinion call for the application of a mixed mode research framework.

\section{References}

[1] Abramo, G., Cicero, T. and D'Angelo, C.A. (2015): Should the research performance of scientists be distinguished by gender? Journal of Informetrics, 9, 25-38.

[2] Allen, T.D., Day, F. and Lentz, E. (2005): The role of interpersonal comfort in mentoring relationships. Journal of Career Development, 31(3), 155-169.

[3] Allen, T.D., Eby, L.T. and Lentz, E. (2006): Mentorship behaviors and mentorship quality associated with formal mentoring programs: Closing the gap between research and practice. Journal of Applied Psychology, 91(3), 567-578.

[4] Alvarez, A.R. and Lazzari, M.M. (2016): Feminist mentoring and relational cultural theory: A case example and implications. Journal of Women and Social Work, 31(1), $41-54$. 
[5] Arsenjuk, U. and Vidmar, D. (2015): Karierne poti doktoric in doktorjev znanosti. Ljubljana: Statistični urad Republike Slovenije.

[6] Barker, E.R. (2006): Mentoring - A complex relationship. Journal of The American Academy of Nurse Practitioners, 18(2), 56-61.

[7] Barlow, M. (2005): Abolishing "effortless perfection". National Education Association, 23(2), 6-7.

[8] Bell, A. and Treleaven, L. (2011): Looking for professor right: Mentee selection of mentors in a formal mentoring program. Higher Education, 61(5), 545-561.

[9] Beyene, T., Anglin, M., Sanchez, W. and Ballou, M. (2002): Mentoring and relational mutuality: Protégé perspectives. Journal of Humanistic Counselling, Education and Development, 41, 87-102.

[10] Blackburn, R.T., Behymer, C.E. and Hall, D.E. (1978): Research note: Correlates of faculty publications. Sociology of Education, 51(2), 132-141.

[11] Bordons, M., Morillo, F., Fernández, M.T. and Gómez, I. (2003): One step further in the production of bibliometrics indicators at the micro level: Differences by gender and professional category of scientists. Scientometrics, 57(2), 159-173.

[12] Capó, A.M., Coromina, L., Ferligoj, A., Matelič, U. and Coenders, G. (2007): Networks of PhD students and academic performance: A comparison across countries. Metodološki zvezki, 4(2), 205-217.

[13] Çetin, A.T., Kizil, C. and Zengin, H.İ. (2013): Impact of mentoring on organizational commitment and job satisfaction of accounting-finance academicians employed in Turkey. Emerging Markets Journal, 3(2), 1-28.

[14] Colley, H. (2001): Righting rewritings of the myth of mentor: A critical perspective on career guidance mentoring. British Journal of Guidance \& Counselling, 29(2), 177-97.

[15] Coromina, L., Coenders, G., Ferligoj, A. and Guia, J. (2011): PhD students' research group social capital in two countries: A clustering approach with duocentred network measures. Metodološki zvezki, 8(2), 137-155.

[16] de Janasz, S.C. and Sullivan, S.E. (2004): Multiple mentoring in academe: Developing the professorial network. Journal of Vocational Behavior, 64(2), 263-283.

[17] Dickson, J., Kirkpatrick-Husk, K., Kendall, D., Longabaugh, J., Patel, A. and Scielzo, S. (2014): Untangling protégé self-reports of mentoring functions: Further meta-analytic understanding. Journal of Career Development, 41(4), 263-281.

[18] Eby, L.T. and McManus, S.E. (2004): The protégé's role in negative mentoring experiences. Journal of Vocational Behavior, 65, 255-275. 
[19] Eloy, J.A., Svider, P., Chandrasekhar, S.S., Husain, Q., Mauro, K.M., Setzen, M. and Baredes, S. (2013): Gender disparities in scholarly productivity within academic otolaryngology departments. Otolaryngology - Head and Neck Surgery, 148(2), 215-222.

[20] Ensher, E.A., Grant-Vallone, E.J. and Marelich, W.D. (2002): Effects of perceived attitudinal and demographic similarity on protégés' support and satisfaction gained from their mentoring relationships. Journal of Applied Social Psychology, 32(7), $1407-1430$

[21] Füger, H. and Höppel, D. (2011): Can Mentoring Bring Gender Issues into Academic Staff Development? In H. Füger and D. Höppel (Eds.): Mentoring for Change. A Focus on Mentors and Their Role in Advancing Gender Equality, 4-10. Fribourg: eument-net.

[22] Gardiner, M., Tiggemann, M., Kearns, K. and Mrshall, K. (2007): Show me the money! An empirical analysis of mentoring outcomes for women in academia. Higher Education Research \& Development, 26(4), 425-442.

[23] Ghosh, R. (2014): Antecedents of mentoring support: A meta-analysis of individual, relational, and structural or organizational factors. Journal of Vocational Behavior, 84(3), 367-384.

[24] Gu, J., Lin, Y., Vogel, D. and Tian, W. (2011): What are the major impact factors on research performance of young doctorate holders in science in China: A USTC survey. Higher Education, 62, 483-502.

[25] Hlebec, V., Kogovšek, T. and Ferligoj, A. (2011): The influence of social support and personal networks on doctoral student performance Metodološki zvezki, 8(2), $157-171$.

[26] Hunter, L.A. and Leahey, E. (2010): Parenting and research productivity: New evidence and methods. Social Studies of Science, 40(3), 433-451.

[27] Johnson, W.B. (2002): The intentional mentor: Strategies and guidelines for the practice of mentoring. Professional Psychology: Research and Practice, 33(1), 8896.

[28] Kaufman R.R. and Chevan J. (2011): The gender gap in peer-reviewed publication by physical therapy faculty members: A productivity puzzle. Physical Therapy, 91(1), 122-131.

[29] Kirchmeyer, C. (2005): The effects of mentoring on academic careers over time: Testing performance and political perspectives. Human Relations, 58(5), 637-660.

[30] Koberg, C.S., Boss, R.W., Chappell, D. and Ringer, R.C. (1994): Correlates and consequences of protégé mentoring in a large hospital. Group \& Organization Management, 19(2), 219-39. 
[31] Kochan, F.K. and Trimble, S.B. (2000): From mentoring to co-mentoring: Establishing collaborative relationships. Theory into Practice, 39(1), 20-28.

[32] Kogovšek, T., Hlebec, V. and Ferligoj, A. (2011): From busy bees to science geeks and party animals: A typology of Slovenian doctoral students. Metodološki zvezki, 4(2), 121-136.

[33] Kurtz-Costes, B., Helmke, L.A. and Ülkü-Steiner, B. (2006): Gender and doctoral studies: The perceptions of Ph.D. students in an American university. Gender and Education, 18(2), 137-155.

[34] Lankau, M. J., Riordan, C. M. and Thomas, C. H. (2005): The effects of similarity and liking in formal relationships between mentors and protégés. Journal of Vocational Behavior, 67, 252-265.

[35] Lopez, S.A., Svider, P.F., Misra, P., Bhagat, N., Lnger, P.D. and Eloy, J.A. (2014): Gender differences in promotion and scholarly impact: An analysis of 1460 academic ophthalmologists. Journal of Surgical Education, 71(6), 851-859.

[36] Matelič, U., Mali, F. and Ferligoj, A. (2007): Kreativno okolje in uspešnost mladih raziskovalcev. Družboslovne razprave, 23(55), 71-94.

[37] Meerabeau, L. (2005): The invisible (inaudible) woman: Nursing in the English academy. Gender, Work \& Organization, 12(2), 124-146.

[38] Menges, C. (2016): Toward improving the effectiveness of formal mentoring programs: Matching by personality matters. Group \& Organization Management, 41(1), 98-129.

[39] Merriam, S.B., Thomas, T.K. and Zeph, C.P. (1987): Mentoring in higher education: What we know now. Review of Higher Education, 11(2), 199-210.

[40] Morley, L. (2016): Troubling intra-actions: Gender, neo-liberalism and researcö in global economy. Journal of Education Policy, 31(1), 28-45.

[41] Muschallik, J. and Pull, K. (2016): Minoring in higher education: Does it enhance mentees' research productivity? Education Economics, 24(2), 210-223.

[42] Nöbauer, H. and Genetti, E. (2008): Establishing Mentoring in Europe: Introduction to the Guideline Manual. In H. Nöbauer and E. Genetti (Eds.): Establishing Mentoring in Europe. Strategies for the Promotion of Women Academics and Researchers, 14-16. Fribourg: eument-net.

[43] Nolan, D. (1992): Women in statistics in academe: Mentors matter. Statistical Science, 7(2), 267-272.

[44] O’Brien, K.E., Biga, A., Kessler, S.R. and Allen, T.D. (2010): A meta-analytic investigation of gender differences in mentoring. Journal of Management, 36(2), 537-554. 
[45] Ortiz-Walters, R. and Gilson, L.L. (2005): Mentoring in academia: An examination of the experiences of protégés of color. Journal of Vocational Behavior, 67(3), 459475.

[46] Paglis, L.L., Green, S.G. and Bauer, T.N. (2006): Does adviser mentoring add value? A longitudinal study of mentoring and doctoral student outcomes. Research in Higher Education, 47(4), 451-475.

[47] Paik, A.M., Mady, L.J., Villaneueva, N.L., Goljo, E., Svider, P.F., Ciminello, F. and Eloy, J.A. (2014): Research productivity and gender disparities: A look at academic plastic surgery. Journal of Surgical Education, 71(4), 593-600.

[48] Ponce, A.N., Williams, M.K. and Allen, G.J. (2005): Toward promoting generative cultures of intentional mentoring within academic settings. Journal of Clinical Psychology, 61(9), 1159-1163.

[49] Raabe, B. and Beehr, T.A. (2003): Formal mentoring versus supervisor and coworker relationships: Differences in perceptions and impact. Journal of Organizational Behavior, 24(3), 271-293.

[50] Ragins, B.R. (1997): Diversified mentoring relationships in organizations: A power perspective. Academy of Management Review, 22, 482-521.

[51] Russell, J.E.A. and Adams, D.M. (1997): The changing nature of mentoring in organizations: An introduction to the special issue on mentoring in organizations. Journal of Vocational Behavior, 51(1), 1-14.

[52] Savage, H.E., Karp, R.S. and Logue, R. (2004): Faculty mentorship at colleges and universities. College Teaching, 52, 21-24.

[53] Scandura, T.A. and Williams, E.A. (2001): An investigation of the moderating effects of gender on the relationships between mentoring initiation and protégé perceptions of mentoring functions. Journal of Vocational Behavior, 59, 342-363.

[54] Searby, L. and Tripses, J. (2006): Breaking perceptions of "old boys' networks": Women leaders learning to make the most of mentoring relationships. Journal of Women in Educational Leadership, 4(3), 179-195.

[55] Settles, I.H., Cortina, L.M., Malley, J. and Stewart, A.J. (2006): The climate for women in academic science: The good, the bad, and the changeable. Psychology of Women Quarterly, 30(1), 47-58.

[56] Smith, J.S., Fox, G.L., "Sunny” Park, S.H. and Lee, L. (2008): Institutional antecedents to research productivity in operations: The US perspective. Journal of Operations \& Production Management, 28(1), 7-26.

[57] Sorcinelli, M. D. and Yun, J. (2007): From mentor to mentoring networks: Mentoring in the new academy. Change: The Magazine of Higher Learning, 39(6), 58-61. 
[58] Straus, S.E., Chatur, F. and Taylor, M. (2009): Issues in the mentor-mentee relationship in academic medicine: A qualitative study. Academic Medicine, 84(1), $135-139$.

[59] Townsend, G.C. (2002): People who make a difference: Mentors and role models. ACM SIGCSE Bulletin, 34(2), 57-61.

[60] Ugrin, J.C., Odom, J.D. and Pearson, J.M. (2008): Exploring the importance of mentoring for new scholars: A social exchange perspective. Journal of Information Systems Education, 19(3), 343-350.

[61] Van Eck Peluchette, J. and Jeanquart, S. (2000): Professionals' use of different mentor sources at various career stages: Implications for career success. The Journal of Social Psychology, 140(5), 549-564.

[62] Villarroya, A., Barrios, M., Borrego, A. and Frías, A. (2008): PhD theses in Spain: A gender study covering the years 1990-2004. Scientometrics, 77(3), 469-483.

[63] Weinberg, F.J. and Lankau, M.J. (2011): Formal mentoring programs: A mentorcentric and longitudinal analysis. Journal of Management, 37(6), 1527-1557.

[64] Williamson, I.O. and Cable, D.M. (2003): Predicting early career research productivity: The case of management faculty. Journal of Organizational Behavior, 24(1), $25-44$.

[65] Ziherl, P., Iglič, H. and Ferligoj, A. (2006): Research groups' social capital: A clustering approach. Metodološki zvezki, 3(2), 217-237. 